\title{
Creating proximity across distances - Management tools to support performance and employee well-being.
}

Ipsen, Christine; Poulsen, Signe

Publication date:

2017

Document Version

Peer reviewed version

Link back to DTU Orbit

Citation (APA):

Ipsen, C., \& Poulsen, S. (2017). Creating proximity across distances - Management tools to support performance and employee well-being.. Abstract from 12th International Conference on Occupational Stress and Health, Minneapolis, Minnesota, United States.

\section{General rights}

Copyright and moral rights for the publications made accessible in the public portal are retained by the authors and/or other copyright owners and it is a condition of accessing publications that users recognise and abide by the legal requirements associated with these rights.

- Users may download and print one copy of any publication from the public portal for the purpose of private study or research.

- You may not further distribute the material or use it for any profit-making activity or commercial gain

- You may freely distribute the URL identifying the publication in the public portal

If you believe that this document breaches copyright please contact us providing details, and we will remove access to the work immediately and investigate your claim 
Final/Revised Abstract $\underline{\text { Submission Instructions }}$

TITLE

Start on the first line within the form. Indent ALL TITLE LINES $1 \frac{1}{2} 2$ ". Do not center. Type the entire title in CAPITAL LETTERS.

Double-space between title and authors.

\section{AUTHORS}

Start at the left margin. Do not indent. List all authors IN

\section{CORRECT ORDER,}

including co-authors, along with affiliation. Use capitals and lower case.

For the abstract of a symposium as a whole, list the name of the chair first, the presenters, and the discussant last. List each affiliation after the person's name. Also, prepare an abstract for each presenter's paper, listing the presenter first, followed by any additional authors for that paper. Double-space between authors and the first line of the abstract.

\section{$\underline{\text { ABSTRACT }}$ \\ Indent each paragraph. Use capitals and lower case, single-spaced. Do not double-space between paragraphs within the abstract. Do not include tables, graphs, charts or references.}

\section{ADDRESS}

Start at the left margin. Using all capitals type: "CORRESPONDING AUTHOR:”. List full name, zip/postal code, and country. Do not exceed the margins as noted. Please include email address.

\section{SAMPLE ABSTRACT - YOU MUST SUBMIT A FINAL ABSTACT THAT CONFORMS TO THIS EXAMPLE; THERE MAY OR MAY NOT BE REVISIONS FROM YOUR ORIGINALLY SUBMITTED ABSTRACT:}

\author{
CREATING PROXIMITY ACROSS DISTANCES - \\ MANAGEMENT TOOLS TO SUPPORT \\ PERFORMANCE AND EMPLOYEE WELL-BEING
}

Christine Ipsen, $\mathrm{PhD}^{*}$ and Signe Poulsen, PhD, IPM Group, Technical University of Denmark, Denmark,

One consequence of organizations' development and adaptation to societal changes and technological developments is distance work where time or geography separate employees and managers (Fisher \& Fisher 2001). Distance work and management occur at different locations, such as from home (telework), in satellite offices (intra-organizational work), or at the customers' or clients' locations (interorganizational work) (Verburg et al. 2013; Cropper et al. 2008). In inter-organizations, distance employees are employed by one company (the provider) but work at a different company (the customer) (Cropper et al. 2008; Hinds \& Kiesler 2002); here, the customer's working conditions influence the employees. Distance work and management are a characteristic in various types of knowledge work (Fisher \& Fisher, 2001; Jacobs, 2004; Li \& Scullion, 2006) where work-related stress is still an unsolved problem. When either time or geography separate managers from their employees, it becomes more difficult to ensure both the employees psychosocial work environment and organizational performance.

This paper explores distance managers' preventive activities that ensure both employee well-being and performance across distances as part of their daily management. The study contributes to the discussion on management of prevention of work-related stress in the context of distance work.

We applied a case study approach to explore the tools distance managers make use of to ensure employee wellbeing and organizational performance. Data were collected with semi-structured interviews of both distance managers and their employees working in two types of knowledge work (Alvesson 2004) i.e. specialized manufacturing and consultancies in four inter-organizational distance work places.

The researchers conducted $17 \mathrm{semi}$-structured interviews including questions about distance management practices and applied tools along with distance work experiences, especially regarding employee wellbeing and organizational performance. The dataset from the four companies consists of one manager from each company together with up to four of their distance workers located at their customers' companies. The researchers coded the transcribed interviews using template analysis (King 1998) where the research question determined three a priori codes for the data analysis.

This study shows that physical and social working conditions at the work sites, both nationally and internationally, directly affect the employees' wellbeing and thus their performance. As inter-organizational distance work deprives the employees with the ability to meet face-to-face with their manager the distance managers' primary concern therefore is whether the employees perform as expected and according to plan and how they, as managers, can create a sense of proximity and belonging to the company. Dialogue with the distance workers is a core activity and conducted via Skype, phone, Lync or email. The frequency varies from weekly to monthly calls depending on the type of employee and the given situation. Focus in the calls is either on project related issues, which need to be solved, or the performance and well-being 
of the employees. The manager typically initiates the calls.

Beside the direct contact via Skype, Lync and mobile phones, the managers

also apply other management tools and practices to ensure well-being and monitoring performance. The managers thus conduct a systematic monitoring of their contact with their employees (who have they talked with and when). They also make use of ongoing individual follow-up surveys focusing on both well-being and performance to support the distance managers' direct contact with their employees and to monitor changes in either of the two areas.

In the direct contact with the employees they focus first on employee's wellbeing and then on the performance (content) acknowledging that their well-being determines their performance. The dual focus is important as the distance managers recognize that the customers' working conditions have a direct impact on the performance of the distance workers. Besides the direct contact with their employees, the study also shows that continuous expectancy alignment among the customer, employee, project manager and distance manager is an important tool to ensure both performance and well-being. Finally, the template analysis showed that distance workers highly value time to talk and management capabilities i.e. the listening, understanding and/or the acknowledging manager as ways to ensure their well-being prevent them from being stressed.

Acknowledging the impact distance has on management of prevention of work-related stress in the context of distance work future organizational intervention research should also consider the distance (time \&/or geography) between the managers and employees but also who is responsible for the employees' work environment.

The study shows that distance managers apply more than just traditional IT communication tools in their management practice, and that well-being has first priority in the talks with the distance workers besides the focus on performance. The employees however value time to talk and management capabilities like the ability to listen, understand and acknowledge that good working conditions are a prerequisite for their well-being and consequently their performance.

\section{References}

Alvesson, M., 2004. Knowledge Work and Knowledge-Intensive Firms, New York: Oxford University Press.

Cropper, S. et al., 2008. The Oxford Handbook of Inter-Organizational Relations 1st ed. S. Cropper, ed., Oxford University Press.

Fisher, K. \& Fisher, M.D., 2001. The Distance Manager. A Hands-On Guide to Managing Off-Site Employees and Virtual Teams, McGraw-Hill.

Hinds, P. \& Kiesler, S., 2002. Distributed Work,

King, N., 1998. Template analysis. In C. Casell, ed. Qualitative methods and analysis in organizational research. A practical guide. London: SAGE Publications, pp. 118-134. Maslow, A., 1965. Self-actualization and beyond. Conference of the Training of Counselors of Adults, pp.1-27.

Verburg, R.M., Bosch-Sijtsema, P. \& Vartiainen, M., 2013. Getting it done: Critical success factors for project managers in virtual work settings. International Journal of Project Management, 31(1), pp.68-79.

CORRESPONDING AUTHOR: Christine Ipsen, M.Sc. PhD, Department of Management Engineering, Implementation and Performance Management Group, Technical University of Denmark, Denmark, Produktionstorvet, DK - $2800 \mathrm{Kgs}$ Lyngby, Denmark. 
